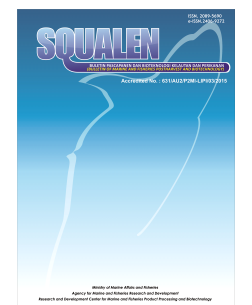

\title{
PHYSICOCHEMICAL CHARACTERISTICS OF SODIUM ALGINATE EXTRACTED FROM Turbinaria sp. AND Sargassum sp.
}

\author{
Rinta Kusumawati, ${ }^{1}$ Jamal Basmal', and Bagus Bandol Utomo' \\ ${ }^{1)}$ Research and Development Center for Marine and Fisheries Product Processing and Biotechnology \\ JI. KS. Tubun Petamburan VI, Jakarta 10260 Indonesia \\ Article history: \\ Received: 8 January 2018; Revised: 20 July 2018; Accepted: 25 August 2018
}

\begin{abstract}
Characterization of sodium alginate extracted from two species of brown seaweeds (Turbinaria sp. and Sargassum sp.) harvested from Binuangeun Beach, Banten, has been conducted. The aim of the study was to evaluate physicochemical characteristics (moisture, whiteness, viscosity, and functional groups) of sodium alginates extracted from Turbinaria sp. and Sargassum sp. Extraction was conducted in acid solution with the following steps: washing, acid extraction, bleaching, alginic acid conversion, sodium alginate conversion, dehydration, and drying. Each extraction was conducted in duplicate using approximately $1 \mathrm{~kg}$ of the dry raw materials (Turbinaria sp. and Sargassum sp.). Results of the analysis showed that the yield of sodium alginate powder extracted from Sargassum sp. was $24.56 \pm 0.56 \%(\mathrm{w} / \mathrm{w})$ with moisture content of $12.69 \pm 1.24 \%$; whiteness degree of $43.80 \pm 1.71 \%$; and viscosity of $143.43 \pm 3.25 \mathrm{cPs}$, while the yield of sodium alginate powder extracted from Turbinaria sp. was $22.69 \pm 2.12 \%(\mathrm{w} / \mathrm{w})$ with moisture content of $14.77 \pm 2.55 \%$; whiteness degree of $23.77 \pm 0.68 \%$; and viscosity of $133.67- \pm 4.04 \mathrm{cPs}$. Meanwhile, the commercial sodium alginate was identified to have moisture content of $16.07 \pm 0.09 \%$, whiteness degree of $29.37 \pm 0.55 \%$ and viscosity of $102.67 \pm 4.04$ cPs. This indicates that physicochemical characteristics of sodium alginate extracted from Sargassum sp. is better than those extracted from Turbinaria sp. and commercial alginate since it had lower moisture content as well as higher whiteness degree and viscosity.
\end{abstract}

Keywords: acid extraction, sodium alginate, Sargassum sp., Turbinaria sp.

\section{Introduction}

Alginate is a hydrocolloid extracted from brown seaweed. According to BPS (2018), Indonesia imported about 1,650 tons of alginate every year which was entirely supplied from imports. As much as $50 \%$ of the imported alginate was used in textile industry, $30 \%$ for food, $6 \%$ for paper production, $5 \%$ for welding rods production, and the other $5 \%$ for pharmaceutical purposes.

Brown seaweed, as a raw material for alginate extraction, can be found in Indonesian waters. Two types of brown seaweeds which grow predominantly in Indonesia are Sargassum sp. and Turbinaria sp. However, not similar to Eucheuma cottonii which has been cultured successfully cultured in many areas in Indonesia, Turbinaria sp. and Sargassum sp. has not been cultured intensively (Purnomo et al, 2017).
Therefore, in order to develop alginate industry in Indonesia, improving the method for alginate for alginate extraction to produce good quality product is very important, besides providing the high capital investment for the raw material sustainability.

There had been several research reports on alginate extraction using acid followed by additional of formalin solution (Reyes-Tisnado, R.,HernandezCarmona, G., Montesinos, Y. E. R., Higuera, D. L. A., \& Gutierrez, F.L. 2005, Jelynne, P., Tamayo, \& Del Rosario, E.J., 2014, Viswanathan \& Nallamuthu, 2014). Other methods were reported using acid solution for extraction and dehydrated using suitable solvent to form fibrous material (Murdinah et al, 2005; Husni, A., Subaryono, Pranoto, Y., Tazwir, \& Ustadi. 2012, Latifi, A.M., Nejad, E.S., \& Babavalian, H., 2015). Research for alginate production commonly used Sargassum sp. as a raw material, however,

${ }^{*}$ Corresponding author.

E-mail: tanjung.1979@gmail.com 
alginate can also actually be extracted from Turbinaria $s p$. Although the resource of Turbinaria $s p$. is still abundance in Indonesia, the experiments on alginate extraction in Indonesia from this species is still limited. Extraction using acid added with isopropyl alcohol (IPA) was chosen in in this study to avoid the use of formalin which is not recommended to be used in food processing. In addition, the use of IPA is able to speed up the drying process as well.

Jothisaraswathi, S., Babu, B., and Rengasamy, R. (2006) reported that alginate extracted from 'the leafy parts' of the seaweed has the highest yield than that extracted from stem or entire thallus of Turbinaria conoides (J.Ag.) Kutz. However, it had the lowest viscosity, and molecular weight than alginate from $S$. binderi and S. baccularia (Chee, S., Wong, P., \& Wong, C. , 2010). Viscosity and molecular weight are specific characteristics of alginate that can indicating the functional properties of alginate in commercial products. Beside the ratio of manuronate and guluronate, other properties such as moisture content, viscosity, whiteness, and functional groups are also important characteristics to determine the quality of alginate.

The aim of the study was to identify physicochemical characteristics (moisture, whiteness, viscosity, and functional groups) of sodium alginates extracted from Turbinaria sp. and Sargassum sp harvested from Binuangen Beach, Banten, Indonesia.

\section{Materials and Method}

\subsection{Materials}

The study used Sargassum sp. and Turbinaria sp. collected from Binuangen beach, Banten, Indonesia, which were harvested during low tide condition. Other materials used were commercial sodium alginate (4mular Irving CA 92614), sodium alginate powder (Aldrich chemistry 9005-38-3), $\mathrm{HCl}$, fresh water, $\mathrm{Na}_{2} \mathrm{CO}_{3}, \mathrm{NaOCl}, \mathrm{NaOH}, \mathrm{C}_{3} \mathrm{H}_{7} \mathrm{OH}$, and chemicals for Fourier-transform Infrared (FTIR) spectroscopy analysis.

\subsection{Method}

\subsubsection{Samples preparation}

The brown seaweeds (Sargassum sp. and Turbinaria sp.) were washed with fresh water followed by cleaning the samples. The samples were sundried and packed hermetically in plastic bag, then transported to laboratory and stored at room temperature for further experiment.

\subsubsection{Sodium alginate extraction}

Sodium alginate extraction was conducted based on Murdinah et al (2005). Kg of dry seaweed, with having moisture content $11.96 \pm 0.03 \%$, were soaked in $1 \%(\mathrm{v} / \mathrm{v}) \mathrm{HCl}$ with ratio of dry seaweed to $\mathrm{HCl}$ solution was 1:30 (w/v), and suspended for 1 hour then neutralized by flowing fresh water. Sodium alginate extraction using neutral raw material was conducted in $2 \%(\mathrm{w} / \mathrm{v}) \mathrm{Na}_{2} \mathrm{CO}_{3}$ at $60-70^{\circ} \mathrm{C}$ for 2 hour, with proportion of dry seaweed to $\mathrm{Na}_{2} \mathrm{CO}_{3}$ solution was 1:30 $(\mathrm{w} / \mathrm{v})$. The suspended material from previous extraction step was re-extracted, filtered and the supernatant was mixed with the first extract then bleached by adding $4 \%(\mathrm{v} / \mathrm{v}) \mathrm{NaOCl}$ slowly for 30 minutes. The alginate solution obtained from extraction process was then acidified by adding $10 \%(\mathrm{v} / \mathrm{v}) \mathrm{HCl}$ until the acidity of the solution reached a pH of $2-3$ and then filtered by using vibrator screen. The solution was converted into sodium alginate by adding $10 \%(w / v) ~ N a O H$ solution until the $\mathrm{pH}$ of the solution was $7-8$. The sodium alginate was then dehydrated using $\mathrm{C}_{3} \mathrm{H}_{7} \mathrm{OH}$ with the proportion of sodium alginate to $\mathrm{C}_{3} \mathrm{H}_{7} \mathrm{OH}$ was $1: 2(\mathrm{v} / \mathrm{v})$ followed by smooth stirring for 30 minutes until solid state of sodium alginate was formed. The solid state of the sodium alginate was dried at $50^{\circ} \mathrm{C}$ for 10 hours and then milled into powder using 100 mesh of sieve plate. This extraction procedure was applied for both Sargassum sp. and Turbinaria sp.

\subsubsection{Mosture content analysis}

Mosture content was analyzed following SNI 2534$1: 2015$ analysis procedure (BSN, 2015). As much as $\pm 2 \mathrm{~g}$ sodium alginate powder, were dried for $18-24$ hours in the oven at $105^{\circ} \mathrm{C}$, then cooled in a desiccator for 30 minutes and weighed after temperature of the samples reach $25^{\circ} \mathrm{C}$. The value of moisture content is the percentage of the weight ratio of the water evaporated to the initial sample weight.

\subsubsection{Viscosity analysis}

Viscosity was measured based on Brookfiled viscometer manual book using Brookfiled LVT model viscometer. 7.5 grams of sodium alginate powder were dissolved in $500 \mathrm{ml}$ of distilled water then stirred slowly at $80^{\circ} \mathrm{C}$ for 30 minutes. Analysis was conducted using a spindle number 2 with $60 \mathrm{rpm}$ speed rotation and keeping the temperature of the solution stable. The stable number indicated by the tool was then multiplied by the conversion factor to obtain a viscosity value. 


\subsubsection{Whiteness degree analysis}

Whiteness degree was measured based on whiteness meter manual procedure using Kett whiteness meter. Measurement using white paper as a standard and powder samples. After measuring absorption of the standard, absorption of the sample measured by filling the sample into whiteness meter chamber until full and compact. The whiteness value indicated by the tool is the percentage of the trend toward the white color of the sample.

\subsubsection{Functional groups analysis}

The FTIR (Perkin-Elmer 577) was used to analyze of functional groups of the sample using procedure manual for $\mathrm{KBr}$ pellet method and $\mathrm{M}-80$ spedcord. One milligram of sample was crushed with $200 \mathrm{mg}$ $\mathrm{KBr}$ until it was homogeneous. The powder was pressed into a thin tablet and placed in a sample pan. Infrared uptake was measured at a waveleth of 400$4,000 \mathrm{~cm}^{-1}$.

\subsubsection{Data analysis}

The experimental design used in this study was Completely Randomized Design with three replications. Data obtained were analyzed using MSexcel program.

\section{Result and Discussion}

The yield of sodium alginate extracted from Sargassum sp. was $24.56 \%$, higher than Turbinaria sp. which was only $14.77 \%$. It was probably due to the difference in the thallus hardness. The thallus of Sargassum sp. was softer than that of Turbinaria sp. Stiger, Deslandes, and Payr (2004) found that morphological point of view affected the yield of sodium alginate extract. Due to their thallus texture difference, extracting alginate from Sargassum sp is easier than from Turbinaria sp, thus the yield of alginate which can be extracted from Sargassum sp was also higher than that from Turbinaria sp, Stiger et al (2004) also found that morphologically, Sargassum sp has softer and more flexible thallus than Turbinaria sp. which was strongly embeded to corral reef. Extracting alginate from Turbinaria probably needs additional treatment to produce an optimal or even maximum yield. It could be done by using higher concentration of extracting solution or temperature. However, further study related to this needs to be conducted.

For commercial production, Sargassum sp. as raw material has a better opportunity to be developed because this seaweed is more easily found in Indonesian coastal area. However, this type of seaweed has not been cultivated commercialy, even though the cultivation experiment conducted in 2000 at Binuangeun Beach was quite successful (Kusumawati, 2011). According to Soegiarto, A., Soelistijo, Atmadja, W.S. \&Mubarak, H. (1978), yield of alginate is depent on the type of seaweed, the environmental condition and season, whereas Budiyanto and Djazuliu (1997) mentioned that the yield 0 alginate depended on light intensity, water current, nutritional condition, the age of the seaweed, method of handling as well as extraction techniques. Yulianto (1997) stated that pre-treatment which was conducted

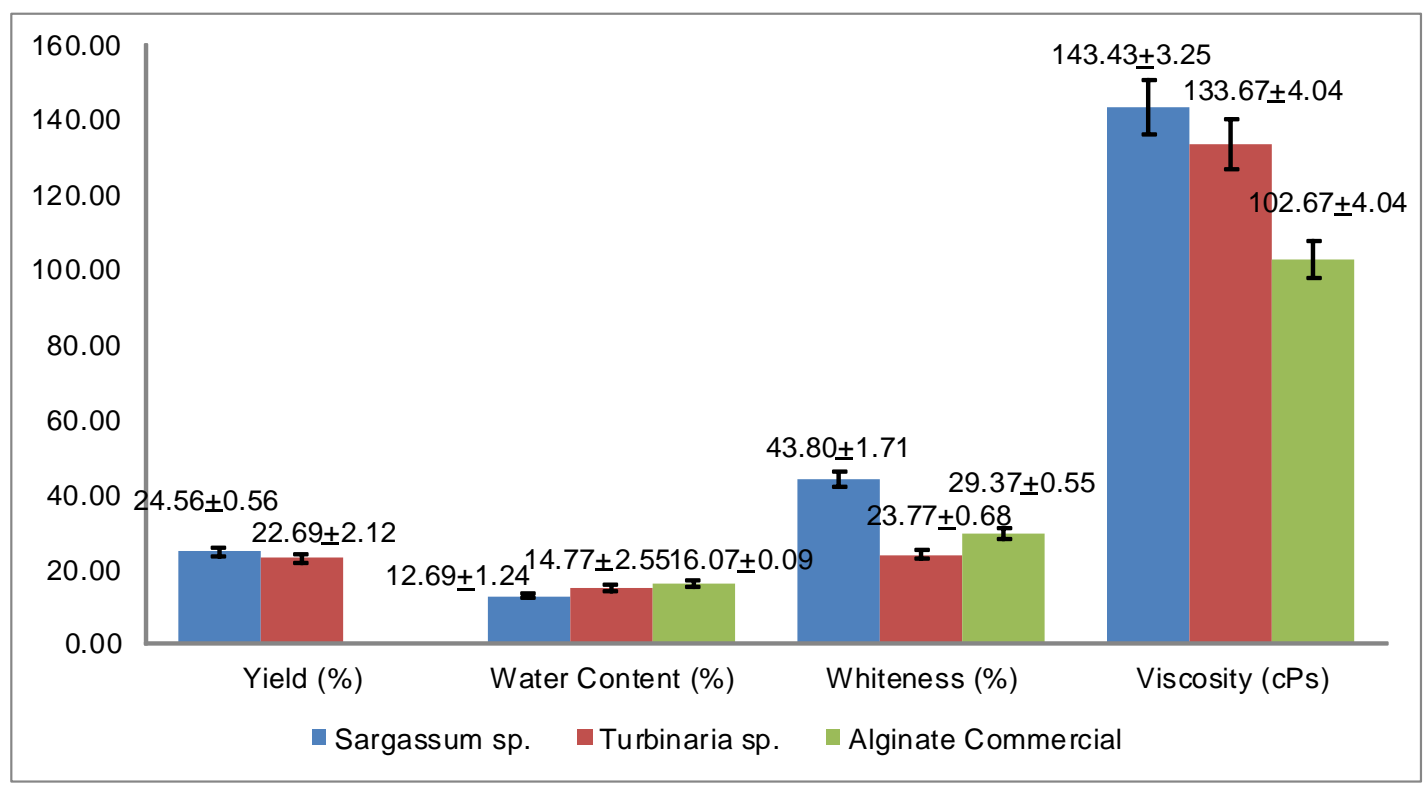

Figure 1. Yield and characteristics of alginate extracted from Sargassum sp. and Turbinaria sp. 


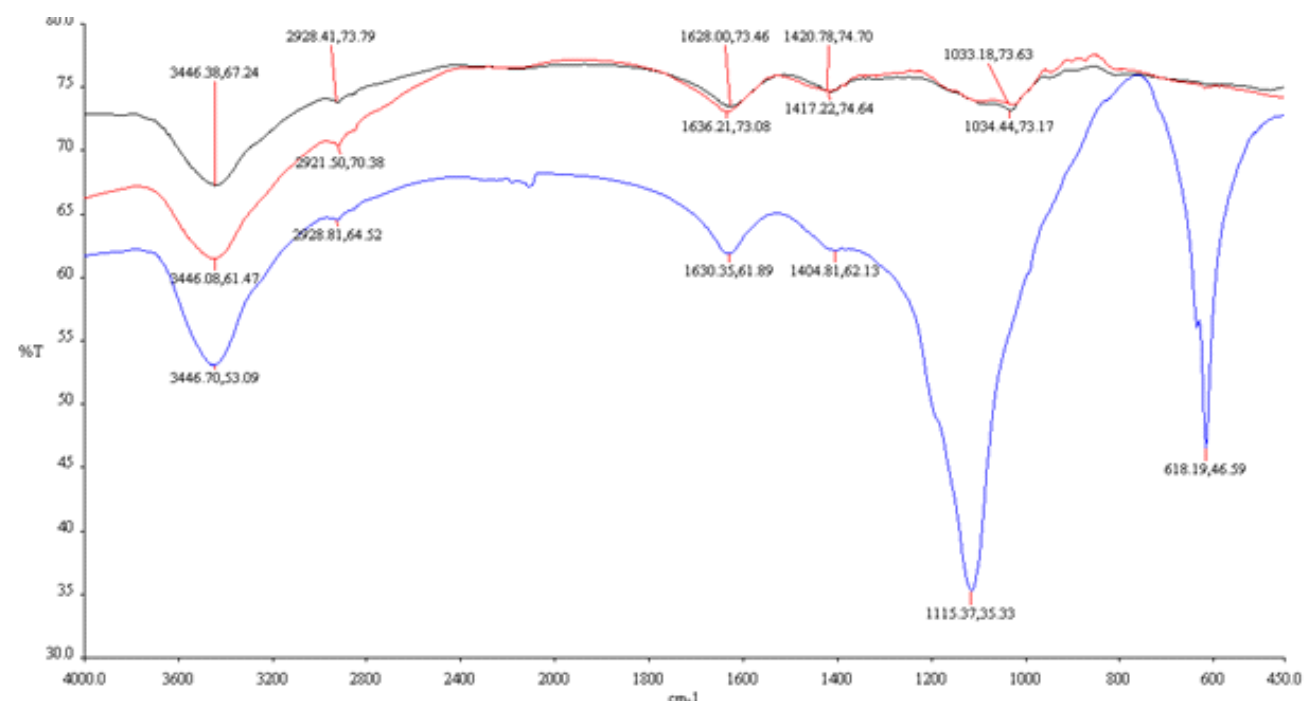

Figure 2. FT-IR spectrum of sodium alginic standard, and sodium alginic extracted from Sargassum sp. and Turbinaria sp.

before extraction was very important factor in determining the quality of the extracted alginate.

Water content affected the shelf life of the product. Nasir et.al (2013) reported that the shelf life of powder are depending very much on the water content which affects especially on microbiological activity and insect infestation. The higher the moisture content the faster is the growth of fungi and also insects infestation, means that the lower the moisture content of alginate powder the longer is its shelf life. Sodium alginate powder extracted from Sargassum sp. had moisture content of $12.69 \pm 1.24 \%$, lower than that from Turbinaria sp., which was $14.77 \pm 2.55 \%$. Since the structure of sodium alginate extracted from both brown seaweed might has some differences, the position of water trapped inside the polymer of alginate may also be different. It needs more research regarding the type and characteristics of the polymer in relation to water trapped in the products. Comparing to commercial sodium alginate powder which had moisture content of $16.07 \pm 0.09 \%$, the alginate extracted from Sargassum sp. and Turbinaria sp. have lower moisture content, meaning that those products might have longer shelf life due to lower microbial activity and growth of fungi.

Whiteness degree of alginate powder is correlated with the use of alginate in food and pharmaceutical industry. The high degree of alginate powder's brightness or whiteness, would give browning effect to the natural color of the main material in formulation. In this study, the whiteness degree of sodium alginate from Sargassum sp. was higher than alginate from Turbinaria sp. $(43.80 \pm 1.71$ and $23.77 \pm 0.68 \%)$ as well as sodium alginate commercial $(29.37 \pm 0.55 \%)$. This phenomenon showed similar contend to the moisture content.

Similarly, viscosity of alginate powder is associated with its function as emulsifier or binder in product formulation in food and pharmaceutical industry. Until recently, Indonesia is still importing alginate for this purpose because it requires a specific viscosity of alginate. Production of alginate powder that meeting the specification needed can support the industrial demand and reduce alginate imports. The viscosity of sodium alginate from Sargassum sp $(143.43 \pm 3.25$ cPs) was higher than alginate from Turbinaria sp. (133.67 $\pm 4.04 \mathrm{cPs})$. Both of sodium alginates have higher viscosity values than sodium alginate commercial (102.67+4.04 cPs). Viscosity is important physical characteristic for alginate, since concentrations of alginate in water causing thickening effect during stirring process (McHugh, 1987). In order to get a thickening effect in a product a small amount of high viscosity alginate can simply be added into formulation.

Quantitative information to describe the functional groups and composition of sodium alginate is very important. This prarameter was analyzed using FT-IR spectroscopy (Figure 2). A band at around $3,400 \mathrm{~cm}^{\text {- }}$ ${ }^{1}$ was attributed to $\mathrm{O}-\mathrm{H}$ stretching vibration, a band at around 2,900 and $1,600 \mathrm{~cm}^{-1}$ was attributed to $\mathrm{C}-\mathrm{H}$ stretching to carboxylate group, while a band at around 1,400 and $1,600 \mathrm{~cm}^{-1}$ indicated the presence of carbonyl group (Daemi \& Barikani (2012), Gholamipoor et al. (2013), and Liu et al. (2016)). the absorbance values of sodium alginate extracted from Sargassum sp. and Turbinaria sp. were not at the same band, indicating that they had different ability in absorbing 
Table 1. Absorbance band of sodium alginate standard, sodium alginate extracted from Sargassum sp. and Turbinaria sp.

\begin{tabular}{|c|c|c|c|c|}
\hline & Sodium Alginate & $\begin{array}{l}\text { Sodium Alginate } \\
\text { extracted }\end{array}$ & $\begin{array}{c}\text { Sodium Alginate } \\
\text { extracted }\end{array}$ & Assignments \\
\hline No & $\begin{array}{l}\text { Standard } \\
\qquad\left(\mathrm{cm}^{-1}\right)\end{array}$ & $\begin{array}{l}\text { From Sargassum sp. } \\
\qquad\left(\mathrm{cm}^{-1}\right)\end{array}$ & $\begin{array}{l}\text { From Sargassum sp. } \\
\qquad\left(\mathrm{cm}^{-1}\right)\end{array}$ & (Fertah et al, 2017) \\
\hline 1 & $3,446.38$ & $3,446.08$ & $3,446.70$ & $\begin{array}{l}\text { Hydrogen bonded O-H } \\
\text { stretching vibration }\end{array}$ \\
\hline 2 & $2,928.41$ & $2,921.50$ & $2,928.81$ & $\mathrm{C}-\mathrm{H}$ stretching vibration \\
\hline 3 & $1,628.00$ & $1,636.21$ & $1,630.35$ & $\begin{array}{l}\text { Asymmetric stretching of } \\
\text { carboxylate O-C-O } \\
\text { vibration }\end{array}$ \\
\hline 4 & $1,420.78$ & $1,417.22$ & $1,404.81$ & $\begin{array}{l}\text { Symmetric stretching } \\
\text { vibration of the } \\
\text { carboxylate group }\end{array}$ \\
\hline 5 & $1,033.18$ & $1,034.44$ & $1,115.37$ & $\begin{array}{l}\text { Due to C-O stretching } \\
\text { vibrations }\end{array}$ \\
\hline
\end{tabular}

infrared light. Table 1 is the summary of the absorbance band characteristics around $3400-1000 \mathrm{~cm}^{1}$.

Based on FTIR analysis, alginate extracted from Sargassum sp. and Turbinariasp. had a characteristic of high absorbance intensity at specific frequency. These specific frequency was very similar to those of the alginate standard used in the experiment, ie. $3,446.38 ; 2,928.41 ; 1,628.41 ; 1.628 ; 1,420.78$, and $1.033 .18 \mathrm{~cm}^{-1}$. Some frequency were not exactly the same with the standard, they were slightly different (a little bid higher or lower) due to atomic bounding interaction.

Pereira, L, Gheda, S.F., \& Ribeiro-Claro, J.A. (2013) reported that manuronate and guluronate ratio $(M / G)$ of alginate can be tentatively estimated at band value around 1,030 to $1,080 \mathrm{~cm}^{-1}$ in infrared spectra. The result showed that intense broad band of sodium alginate extracted from Turbinaria sp. centered at around $1,030 \mathrm{~cm}^{-1}$ of band absorbance, might indicate that the sample contain a lot of guluronate acid (Pereira et al, 2013). The band shifting seems to happen on sodium alginate extracted from Sargassum sp. which may be caused due to the existence of impurities. To determine which type and quantity of impurities affected the band shifting, further study need to be conducted.

\section{Conclusion}

Sodium alginate extracted from Sargassum $\mathrm{sp}$. has yield of $24.56 \pm 0.56 \%$, moisture content of
$12.69 \pm 1.24 \%$, whiteness degree of $43.80 \pm 1.71 \%$ and viscosity of $143.43 \pm 3.25 \mathrm{cPs}$; while sodium alginate extracted from Turbinaria sp. has yield of $22.69 \pm 2.12 \%$, water content of $14.77 \pm 2.55 \%$, whiteness degree of $23.77 \pm 0.68 \%$ and viscosity of $133.67 \pm 4.04 \mathrm{cPs}$. Meanwhile, the commercial sodium alginate was identified to have moisture content of $16.07 \pm 0.09 \%$, whiteness meter of $29.37 \pm 0.55 \%$ and viscosity of $102.67+4.04 \mathrm{cPs}$ The physicochemical characteristics of sodium alginate extracted from Sargassum sp. is better than those extracted from Turbinaria sp. and commercial alginate since it had lower moisture content as well as higher whiteness degree and viscosity.

\section{References}

Badan Pusat Statistik (2018). Expor dan Impor: Tabel Impor Menurut Komiditi, Tahun 2017.

Badan Standardisasi Nasional. (2015). SNI 2354-22015 Cara ujikimia - Bagian 2: Pengujian kadar air pada produk perikanan.Jakarta: Author. Budiyanto and Djazul. (1997). Teknologi Pengolahan Alginat dari beberapa jenis Rumput Laut Marga Sargassum sp. Jurnal Pascapanen Perikana, (V)1, 12-16.

Chee, S., Wong, P., \&Wong, C. (2010). Extraction and characterization of alginate from brown seaweeds (Fucales, Phaeophyceae) collected from Port Dickson, Peninsular Malaysia. Journal of Applied Phycology, 23(2), 191.

Daemi, H.and Barikani, M. (2012). Synthesis and characterization of calcium alginate nanoparticles, 
sodium homopolymannuronate salt and its calcium nanoparticles. Scientia Iranica, 19, 2023-2028.

Fertah, M., Belfkira, A., Dahmane. E., Taourirte, M., \&Brouillett, F. (2017). Extraction and characterization of sodium alginate from Moroccan Laminaria digitata brown seaweed. Arabian Journal of Chemistry, 10(2), S3711-S3712.

Gholamipoor, S., Nikpour-Ghanavati, Y., Oromiehie, A. R., \&Mohammadi, M. (2013). Extraction and Characterization of Alginate from Sargassum angustifolium Collected from Northern Coasts of Persian Gulf, Bushehr. International Symposium on Advanced in Science and Technology, 1-5.

Husni, A., Subaryono, Pranoto, Y., Tazwir, \&Ustadi. (2012). Pengembangan Metode Ekstraksi Alginat dari Rumput Laut Sargassum sp. sebagai Bahan Pengental. Agritech, 32(1), 2-3.

Jelynne, P.; Tamayo, \& Del Rosario, E. J. (2014). Chemical analysis and utilization of Sargassum sp. as Substrate for Ethanol Production. Iranica Journal of Energy \& Environment, 5(2), 203.

Jothisaraswathi, S., Babu, B., \& Rengasamy, R. (2006). Seasonal studies on alginate and its composition II: Turbinaria conoides (J.Ag.) Kutz. (Fucales, Phaeophyceae). Journal Application Phycology. Springer Science Business Media. 18(2), 161-166. doi.org/10.1007/s10811-006-9089-8.

Kett. (2011). Instant Whiteness Tester Rice and Rice Powder. California: Author.

Kusumawati, R. (2011). Penyediaan Sumber Daya Hayati Kelautan sebagai Bahan Baku Bioenergi dalam Perspektif Ekosistem. Tesis. Institut Teknologi Bandung. p.98-100.

Latifi, A. M., Nejad, E. S., \& Babavalian, H. (2015). Comparison of Extraction Different Methods of Sodium Alginate from Brown Alga Sargassum sp. Localized in the Southern of Iran. Journal of Applied Biotechnology Reports, 2(2), 51-255.

Liu, X., Liu, B., Wei, X., Sun, Z., \& Wang, C. (2016). Extraction, Fractionation, and Chemical Characterization of Fucoidans from the Brown Seaweed Sargassum pallidum. Czech. Journal of Food Science, 34(5), 410.

McHugh, D.J. (1987) Production and Utilization of Products from Commercial Seaweeds. FAO Fisheries Technical Paper No. 288, 1-189.
Murdinah, Peranginangin, R., Irianto, H.E., Amini, S., Subaryono, Darmawan, M., Sinurat, E., dan Fransiska, D. (2005). Riset Optimasi Pemanfaatan Makro dan Mikro Alga. Laporan Teknis. Pusat Riset Pengolahan Produk dan Sosial Ekonomi. Jakarta. p.106.

Nasir, M.; Butt, M. S., Anum, F. M.; Sharif, K., \& Minhas, R. (2003). Efect of Moisture on the Self Life of Wheat Flour. International Journal of Agriculture and Biolog, 5(4), 458-459.

Pereira, L, Gheda, S.F., \& Ribeiro-Claro, J.A. (2013). Analysis by vibrational spectroscopy of seaweed polysaccharides with potential use in food, pharmaceutical, and cosmetic industries. International Journal of Carbohydrate Chemstry, 2013, 1-7. dx.doi.org/10.1155/2013/537202.

Perkin Elmer. (2004). Spectrum One User's Guide. Connecticut: Author.

Purnomo, A. H., Utomo, B. S. B.; Wibowo, S.; Basmal, J.; Aji, N., ....... and Octavini, H. (2017). Improving Seaweed Production and Processing Opportunities in Indonesia. Research Report. p. 6-10.

Rafsanjani, H. (2017). Bersinergi Menggarap Bioteknologi Kelautan Indonesia. Newsantara. https:/ /newswantara.com/. Accessed on August $8^{\text {th }}, 2018$.

Reyes-Tisnado, R.; Hernandez-Carmona, G.; Montesinos, Y. E. R.; Higuera, D. L. A.; \&Gutierrez, F. L. (2005). Food grade alginates extracted from the giant kelp Macrocystis pyrifera at pilot-plan scale. Rev. Invest. Mar, 26(3), 186.

Soegiarto, A., Soelistijo, Atmadja, W.S. \&Mubarak, H. (1978). Rumput laut (Alga). Manfaat, Potensi dan Usaha Budidaya. LON-LIPI, Jakarta. P 5-15.

Stiger, V., Deslandes, E., \&Payri, C. E. (2004). Phenolic contents of two brown algae, Turbinaria ornata and Sargassum mangarevense on Tahiti (French Polynesia): interspecific, ontogenic and spatiotemporal variations. Botanica Marina, 47, 402-409.

Viswanathan, S. \& Nallamuthu, T. (2014). Extraction of Sodium Alginate from Selected Seaweeds and Their Physiochemical and Biochemical Properties. International Journal of Innovative Research in Science, Engineering, and Technology, 3(4), 10999.

Yulianto, (1997). Ekstraksi Iginat dari Turbinaria ornate (Turner) J. gardh (Phaeophyceae): Suatu Studi Pendahuluan.Seminar Nasional Biologi $X V$. Balitbang Sumberdaya Laut, P3O-LIPI, Poka Ambon. 